\title{
Awake sedation thoracoscopy for the diagnosis of malignant mesothelioma: a service review
}

Abdullah Alqallaf ${ }^{1 \dagger}$, Mariana Ahmad Zuber ${ }^{1}$, Shehnoor Tarique ${ }^{2}$, Alina A. Ionescu²

${ }^{1}$ Cardiff University School of Medicine, Cardiff, UK

Abstract

${ }^{2}$ Department of Respiratory Medicine, Royal Gwent Hospital, Newport, UK

English:

Background: Mortality from malignant mesothelioma is expected to peak in the UK in the current decade. Areas of the country which have historically high rates of industrial exposure to asbestos, such as South East Wales, are expected to bear a disproportionately high burden of mesothelioma, making a priority. Medical thoracoscopy is an effective and safe procedure, affording both a high diagnostic yield in mesothelioma and an opportunity to carry out therapeutic drainage of pleural effusion.

Methods: We evaluated the diagnostic yield and safety of medical thoracoscopy at our centre over a 5-year period from 2010 to 2015 including 104 consecutive patients.

Results: We found that thoracoscopy provided a conclusive result effected $91.6 \%$ of successful biopsies. Thoracoscopy was especially superior to pleural cytology in the diagnosis of malignant mesothelioma, revealing 37 cases when cytology suggested only 5. The procedure was particularly safe with no mortality and only $6.7 \%$ of patients experiencing minor complications such as hypotension, and more than $75 \%$ of patients tolerated the procedure with mild or no discomfort.

Conclusion: We conclude that the awake sedation thoracoscopy service at our institution is safe and effective, particularly in the diagnosis of mesothelioma, which is common in our area.

Keywords

thoracoscopy $\cdot$ mesothelioma $\cdot$ pleural cytology $\bullet$ asbestos

\section{Toracoscopia medicală cu sedare pentru diagnosticul mezoteliomului malign: evaluarea unei proceduri}

Rezumat

Romanian:

Introducere: Mortalitatea datorată mezoteliomului malign este în creștere; în Marea Britanie se evaluează că maximul de mortalitate va fi în decada actuală. În sudul Tării Galilor, din cauza expunerii la azbest, mezoteliomul malign este frecvent. Din acest motiv, metode precise și rapide de diagnostic sunt prioritare pentru a permite un tratament prompt și a oferi pacienților posibilitatea de a aplica pentru schema guvernamentală de compensare pentru boli industriale.

Metodologie: Studiul de față evaluează rata diagnostică și complicațiile toracoscopiei medicale, efectuată de pneumologi cu sedare și include 104 cazuri consecutive în decurs de 5 ani intre 2010 și 2015. O parte a pacienților au evaluat discomfortul în timpul procedurii pe o scală cu 6 puncte, evaluare introdusă de rutină în 2013. Toracoscopiile efectuate în centrul nostru de diagnostic sunt documentate într-o bază de date care cuprinde informații demografice, rezultatul histologic, tipul și doza de sedare, complicațiile și scorul de disconfort. Rezultate: în 91.6\% din cazuri s-a obținut rezultat histologic diagnostic. Cazurile non diagnostice s-au datorat în mare parte prezenței aderențelor pleurale care nu au permis vizualizarea pleurei parietale, deci biopsiile nu au fost posibile. Procedura diagnostică a avut rata zero de mortalitate; $6.7 \%$ din cazuri au fost complicații minore e.g. hipotensiune tranzitorie fără repercusiuni de durată sau un grad de emfizem subcutanat. Toracoscopia a fost bine tolerată, peste $75 \%$ din cazuri nu au avut niciun disconfort sau disconfort minor. Concluzii: Toracoscopia medicală cu sedare este bine tolerată și cu valoare diagnostică într-un spital regional cu incidență relativ mare a mezoteliomului malign.

Cuvinte-cheie

toracoscopie $\cdot$ mezoteliom $\bullet$ citologie pleurală $\bullet$ azbest

${ }^{+}$Corresponding author: Abdullah Alqallaf

E-mail: abdullahalqallaf@hotmail.com

əopen Access. () 2019 Alqallaf et al., published by Sciendo

(ख) Br.NC-ND This work is licensed under the Creative Commons Attribution-NonCommercial-NoDerivs 4.0 License. 


\section{Introduction}

Malignant mesothelioma, formerly thought to be rare, has been rising in incidence over recent years. It is an almost invariably aggressive malignancy with a median survival of 8-14 months, and its diagnosis remains challenging (1). The causative association with asbestos is well established, although a latency period, from exposure to diagnosis, of more than 20 years is usually observed (2). Exposure to asbestos was endemic in South East Wales in the 20th century giving rise to high incidence of asbestos-related pulmonary disease, including malignant mesothelioma, in our patient population. Epidemiological studies suggest that mortality from mesothelioma in the UK is likely to have reached a peak sometime between 2011 and 2015 (2). This translates into $1,950-2,450$ deaths a year and represents a significant burden on resources, especially with 65,000 deaths predicted between 2001 and 2050 (2). Providing a histological diagnosis of mesothelioma is a major role of thoracoscopy, and the procedure also offers an opportunity to carry out therapeutic measures such as direct drainage of large pleural effusions and pleurodesis. British Thoracic Society (BTS) guidelines on thoracoscopy urge routine clinical audit of diagnostic techniques used to investigate exudative pleural effusions, including missed diagnosis and the need for further procedures (3).

This service review is focused primarily on the diagnostic yield and safety of thoracoscopy in mesothelioma between 2010 and 2015.

\section{Methods}

Awake sedation thoracoscopy reports and electronic patient notes were reviewed retrospectively for patients who underwent the procedure over a 5-year period between April 2010 and April 2015. A database was developed to include patient gender and age at procedure. Previous pleural cytology reports were reviewed and compared to the histology of pleural specimens obtained at thoracoscopy.

With regard to the procedure, we gauged the doses of analgesia and sedation required. Details of the visual inspection of the pleura during thoracoscopy, including the presence of nodules, plaques and adhesions, were recorded. Where biopsy was unsuccessful or inconclusive, we reviewed further plans to refer patients for video-assisted thoracic surgery (VATS).

Safety analysis involved determining the rate of major and minor complications. In addition, we analysed the 6-point patient-perceived comfort score, which was introduced to the service in 2013 , to examine how well the procedure was tolerated.

\section{Results}

This service review included 104 consecutive patients who underwent thoracoscopy over a 5-year period from April 2010 to April 2015. Seventy-one were male (68\%), and 33 were female $(32 \%)$. The age range varied widely from 36 to 92 years (mean 70.4 years, median 71 years). Thoracoscopy was performed on the right pleural cavity in the majority of patients $(59.6 \%)$. The mean dose of midazolam sedation was $3 \mathrm{mg}$ (range 1-6), and the mean dose of alfenatyl analgesia was $332 \mathrm{microgram} / \mathrm{mcg} /$ (range 0-1,000).

The most common findings on inspection of the pleural cavity were nodular changes (73\%), pleural plaques $(38.4 \%)$, pleural adhesions (25.9\%) and suspected lung entrapment $(12.5 \%)$. Sixty-seven $(64.4 \%)$ patients underwent talc pleurodesis during the procedure, whilst 16 patients $(15.3 \%)$ had a tunnelled indwelling pleural catheter (TIPC) inserted.

Results of cytological examination of pleural fluid obtained by a separate pleural aspiration procedure prior to thoracoscopy revealed 36 malignancies including only 5 mesotheliomas.

During thoracoscopy, biopsies were obtained in the vast majority of cases, but were unsuccessful or limited in 9 patients. Of the successful biopsies, the most common diagnosis was mesothelioma, which was diagnosed or highly suspected in 37 patients $(35.6 \%)$. The second most common diagnosis was benign inflammatory change (24\%), followed by adenocarcinoma of different origins (20\%) and pleural fibrosis (7.7\%; Table 1).

Biopsies were limited or not possible in 9 cases. Six of these were due to dense adhesions or heavily loculated effusions, 1 was due to insufficient sampling (histology showed fat only) and 2 were due to technical malfunction. After discussion with individual patients, 8 were referred to the thoracic surgery service for VATS. Five patients were referred for VATS because biopsies were limited or not possible as stated above, and in

Table 1. Histological diagnoses of samples obtained at thoracoscopy

\begin{tabular}{llc}
\hline Diagnosis & & $\mathbf{N}(\mathbf{\%}) \mathbf{( n = 1 0 4 )}$ \\
\hline Pleural fibrosis & & $8(7.7)$ \\
Nonspecific inflammation & & $25(24)$ \\
Mesothelioma & Type not given & $2(1.9)$ \\
& Epithelioid & $27(26)$ \\
& Sarcomatoid & $2(1.9)$ \\
& Biphasic & $1(1)$ \\
Adenocarcinoma & Suspected & $5(4.8)$ \\
& Lung & $4(2.8)$ \\
& Colon & $2(1.9)$ \\
Papillary carcinoma & Breast & $3(2.9)$ \\
Lymphoma & Endometrial & $1(1)$ \\
Neuroendocrine tumour & Unknown primary & $11(10.6)$ \\
No/limited biopsy & & $1(1)$ \\
\hline
\end{tabular}


the remaining 3 cases even though biopsies were sufficient, the pathologist recommended further biopsy for confirmation of suspected diagnoses. The results of VATS biopsy revealed 4 mesotheliomas, 1 adenocarcinoma of unknown origin and 3 inflammatory effusions.

Of the 95 successful thoracoscopic biopsies, 87 reported conclusive diagnoses, 5 reported suspected mesothelioma and 3 were inconclusive, and the pathologist recommended further biopsy. The diagnostic yield of successful biopsy providing conclusive diagnosis can thus be calculated as $91.57 \%$.

There was no mortality associated with the procedure, and the morbidity rate was low at $6.7 \%$ : 5 patients had mild hypotension and 2 had surgical emphysema. No major complications (such as empyema and tumour seeding) were observed. A 6 -point patient-perceived discomfort score $(0=$ no discomfort, $5=$ severe discomfort) was introduced in 2013 (included 46 out of 104 patients) and determined the procedure to be generally well tolerated with more than $75 \%$ of patients experiencing mild or no discomfort.

\section{Discussion}

\section{Cytology in mesothelioma}

Studies have shown that $54-85 \%$ of patients with malignant pleural mesothelioma have a pleural effusion at the time of presentation (4). Pooled data from 1,370 patients suggest that the diagnostic yield of pleural fluid cytology for malignancy is $60 \%$ (3). For mesothelioma, however, the diagnostic yield of cytology is much lower, being as low as $32 \%$ and $48 \%$ according to 2 studies $(4,5)$. Our data show that cytology initially suggested 5 mesotheliomas, whereas histological specimens obtained at thoracoscopy revealed 37 mesotheliomas, making the diagnostic yield of pleural cytology only $13.5 \%$ in our patient population (Figure 1). This figure reveals the diagnostic power of thoracoscopy in mesothelioma, where aspiration cytology has been consistently shown to be of limited diagnostic value. This

$$
\text { Cytology }
$$

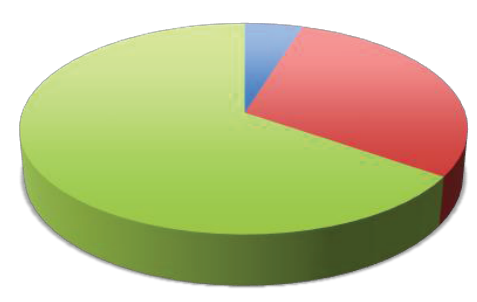

could potentially lead to delays in diagnosis and treatment if further cytological samples are sought prior to proceeding to more advanced diagnostic modalities. Besides a superior diagnostic yield, thoracoscopy affords the benefit of draining pleural effusions and is beneficial in staging.

Furthermore, it is worth noting that these figures pertaining to cytology tend to include a significant number of samples that were merely suspicious as well as those that were diagnostic of mesothelioma, which is another limitation of the diagnostic power of this method. Investigators have often emphasised that distinguishing reactive from malignant mesothelial cells in cytological specimens is often difficult for the pathologist $(4,5)$. This demonstrates that the power of cytological examinations for diagnosing mesothelioma is lower than that of diagnosing other malignancies, such as adenocarcinoma, often necessitating the need for further diagnostic tests $(4,5)$.

\section{Thoracoscopy}

Jacoubes is mentioned as the 'inventor' of thoracoscopy in reference (6) talking about the history of the procedure and has since undergone dramatic advances in equipment and technique, with multiple studies establishing its role as a less invasive alternative to surgical thoracotomy for certain diagnostic and therapeutic indications (6). Medical thoracoscopy is usually performed under local anaesthesia, with the use of narcotics and benzodiazepines (alfentanil and midazolam at our institution) to induce sedation. It has been demonstrated by large studies to be a safe procedure with virtually no mortality $(0.40 \%)$ and low morbidity (2.3\%) consisting mainly of subcutaneous emphysema, transient cardiovascular complications, empyema, fever, excessive bleeding and air embolism $(3,6,7)$. The morbidity rate in our study $(6.7 \%)$ consisted mainly of transient hypotension managed successfully at the endoscopy suite. Moreover, the patient-perceived discomfort score we introduced in 2013 shows that patients' subjective experiences during the procedure are largely favourable. With proper selection of patients and exclusion of those with severe chronic obstructive pulmonary disease,

\section{Thoracoscopy}

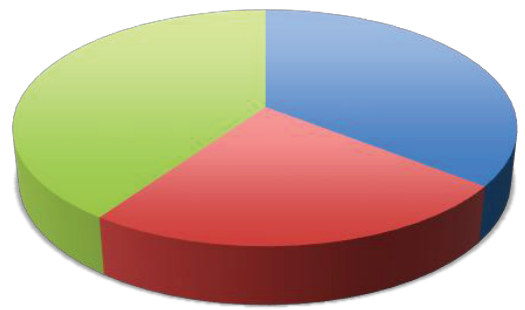

Mesothelioma $\quad$ Other malignancy

Other non-malignant

Figure 1. A comparison between the results obtained from pre-thoracoscopic cytology and the histology of thoracoscopy samples in 104 patients. The majority of cytological samples revealed only reactive lymphocytic cells giving a high false negative rate. 
cardiovascular disease or those on anticoagulants, morbidity can be minimised and a high index of safety can be achieved (6). Loddenkemper (8), a prominent proponent and investigator of medical thoracoscopy, stated that obtaining histological diagnosis of malignant mesothelioma is one of the most useful applications of thoracoscopy. Direct visualisation of the pleura during thoracoscopy allows more representative biopsy, leading to early and accurate histological diagnosis and early treatment (8). Given the historically high asbestos exposure in our patient population, investigating the utility of this technique in the diagnosis of malignant mesothelioma is of importance. Medical thoracoscopy is commonly used in the diagnosis of exudative pleural effusion of unknown origin. Studies show that the most common cause (up to $77 \%$ ) of exudative effusions is malignancy (3). Of our patient population, the pleural effusion was attributed to malignancy in $58 \%$ of the cases (61 patients), consisting of mesothelioma, adenocarcinoma of various origins, lymphoma and others. Almost invariably, patients undergo thoracocentesis with biochemical and cytological examination of the pleural fluid prior to proceeding to thoracoscopy. Although thoracocentesis is usually successful in classifying the pleural effusion as transudative or exudative, using Light's criteria, the definitive diagnostic yield of this technique is low (6). Thoracoscopy has been shown to be superior to cytology alone and cytology plus Abram's needle biopsy in providing a definitive diagnosis in mesothelioma, with sensitivities of $98.4 \%$ vs. $26 \%$ vs. $38.7 \%$, respectively (9). The diagnostic yield of successful biopsies in our study was $91.6 \%$. Pooled data from 22 case series suggest that medical thoracoscopy has a $92.6 \%$ sensitivity for diagnosing malignancy, which is comparable to that achieved by VATS $(3,10)$. This high diagnostic yield is equally true in series examining mesothelioma, which is particularly important given that the sensitivity of pleural cytology is much lower in mesothelioma compared to other malignancies (3). Judicious early use of thoracoscopy may avoid several pleural aspirations in selected patients, leading to earlier diagnosis and treatment. In our series, 8 patients were referred for VATS, returning 4 diagnoses of mesothelioma, 1 adenocarcinoma and 3 benign effusions. It is worth noting that 3 out of these malignancies diagnosed during VATS were suspected from specimens obtained at thoracoscopy, and further VATS biopsies were sought for confirmation. This makes our results consistent with literature showing that the diagnostic power of medical thoracoscopy is comparable to that of VATS.

\section{Conclusions}

Awake sedation thoracoscopy is a safe and effective procedure with a high diagnostic yield of $91.57 \%$ in this service review. This is particularly true when compared to pleural fluid cytology in the diagnosis of malignant pleural mesothelioma, where its role is tremendously valuable. The findings of this review support the argument that expeditious use of thoracoscopy may accelerate the often-elusive diagnostic process of mesothelioma, perhaps affording survival benefit to patients in the future as treatment modalities continue to improve. Thoracoscopy also has therapeutic roles in the treatment of malignant pleural effusion through drainage and pleurodesis. The low rate of morbidity comprised only minor morbidities, and there was no mortality associated with the procedure. We conclude that thoracoscopy is, therefore, a very safe, effective and well-tolerated procedure with particular value in mesothelioma.

\section{Ethics approval and consent to participate}

Not applicable (retrospective study).

\section{Competing interests}

The authors declare that they have no competing interests.

\section{References}

1. Wiggins J. BTS statement on malignant mesothelioma in the UK, 2007. Thorax. 2007;62: ii1-ii19.

2. Hodgson JT, McElvenny DM, Darnton AJ, Price MJ, Peto J. The expected burden of mesothelioma mortality in Great Britain from 2002 to 2050. Br J Cancer. 2005;92(3):587-593.

3. Rahman NM, Ali NJ, Brown G, Chapman SJ, Davies RJ, Downer $\mathrm{NJ}$, et al. Local anaesthetic thoracoscopy: British thoracic society pleural disease guideline 2010. Thorax. 2010;65:54-60.

4. Renshaw AA, Dean BR, Antman KH, Sugarbaker DJ, Cibas ES. The role of cytologic evaluation of pleural fluid in the diagnosis of malignant mesothelioma. Chest. 1997;111(1):106-109.

5. Prakash UBS, Reiman HM. Comparison of needle-biopsy with cytologic analysis for the evaluation of pleural effusion - analysis of 414 cases. Mayo Clinic Proceedings. 1985;60(3):158-164.

6. Rodriguez-Panadero F, Janssen JP, Astoul P. Thoracoscopy: general overview and place in the diagnosis and management of pleural effusion. European Respiratory Journal 2006;28(2):409-421.

7. Hooper C, Lee YCG, Maskell N; BTS Pleural Guideline Group. Investigation of a unilateral pleural effusion in adults: British thoracic society pleural disease guideline 2010. Thorax. 2010;65:4-17.

8. Loddenkemper R. Thoracoscopy - state of the art. European Respiratory Journal. 1998;11(1):213-221

9. Boutin C, Rey F. Thoracoscopy in pleural malignant mesothelioma - a prospective-study of 188 consecutive patients: 1. Diagnosis. Cancer. 1993;72(2):389-393.

10. Harris RJ, Kavuru MS, Rice TW, Kirby TJ. The diagnostic and therapeutic utility of thoracoscopy - a review. Chest. 1995;108(3):828-841. 